\title{
Cytokine SCM-1 Beta
}

National Cancer Institute

\section{Source}

National Cancer Institute. Cytokine SCM-1 Beta. NCI Thesaurus. Code C30153.

Cytokine SCM-1 beta (114 aa, $\sim 13 \mathrm{kDa}$ ) is encoded by the human XCL2 gene. This protein plays a role in lymphocyte chemotaxis. 